\title{
Maximální rozšíření pleistocenního ledovcového štítu ve Vnějších Západních Karpatech a Východních Sudetech - současné znalosti a nový důkaz
}

\author{
Maximum extent of the Pleistocene ice sheet in the Outer Western Carpathians and \\ Eastern Sudetes - current knowledge and new evidence
}

\author{
Martin Hanáček ${ }^{1,2} \square$, Miroslav Bubík ${ }^{3}$ \\ ${ }^{1}$ Vlastivědné muzeum Jesenicka, p. o., Zámecké náměstí 1, 79001 Jeseník, Česká republika \\ ${ }^{2}$ Geografický ústav, Př́rodovědecká fakulta, Masarykova univerzita, Kotlářská 2, 61137 Brno, Česká republika \\ ${ }^{3}$ Česká geologická služba, Leitnerova 22, 60200 Brno, Česká republika
}

Key words:

Slezské Beskydy, Olza River Valley, erratics, maximum extent of ice sheet, Elsterian, Pleistocene

$\underset{\rightrightarrows}{g}$ geolog@muzeumjesenik.cz,

Editor:

Martin Ivanov

\begin{abstract}
A single find of erratic Baltic flint in the Slezské Beskydy Mts. represents a rare evidence of glaciation in the area. The find originates from fluvial deposits of Weichselian valley terrace of the Hluchová Stream, tributary of the Olza River. The erratic was reworked from Elsterian sediments deposited by the Scandinavian Ice Sheet in a very marginal position near its maximum extent in Outer Western Carpathians. Based on morphological analysis, the surface of the erratic was abraded by wave action in the source area on the Baltic shore and subsequently by glacial and (glacio)fluvial transport. Position of the find proves the glaciation of the Olza River valley by a greater ice lobe, than previously assumed.
\end{abstract}

Doporučená citace článku: Hanáček, M., Bubík, M. (2021). Maximální rozšiření pleistocenního ledovcového štítu ve Vnějších Západních Karpatech a Východních Sudetech - současné znalostia nový důkaz. - Geologické výzkumy na Moravě a ve Slezsku, 28, 1-2, $85-92$.

https://doi.org/10.5817/GVMS202115631

\section{Úvod}

Východní Sudety a Karpaty (moravskoslezská glaciální oblast podle Czudka 2005) zasáhl ve středním pleistocénu severoevropský ledovcový štít. Zaledněné území bylo zprvu vymezeno na základě mapování výskytu eratik (klasty hornin cizí, v případě střední Evropy fenoskandicko-baltské a polsko-německé provenience). Rozsah ledovcového štítu v moravskoslezské glaciální oblasti na základě literárních údajů zakreslil např. Drahný (1923). Pozdější plošné geologické mapování i dílčí výzkumy kvartérních sedimentů linii maximálního zalednění zpřesňovaly (obr. 1). Ledovec pokryl celé severní úpatí Rychlebských hor, severní úbočí Rejvízské hornatiny a masivu Biskupské kupy (Gába 1972; Prosová 1981; Otava 1992b; Hanáček, Nývlt 2009). Překryl naprostou většinu Jindřichovické pahorkatiny (Zapletal 1966) a zasáhl do severní části Nízkého Jeseníku. Údolím Opavy ledovec pronikl k Branticím a snad až do prostoru Radimi (Otava 1992a). Východně od údolí Moravice spočívala hranice ledovce zhruba na linii Cvilín-Lichnov-Svobodné Heřmanice (Kroutilík 1960; Czudek 1980; Macoun 1989a; Otava 1992a). Odtud pak maximální hranice zásahu ledovcového štítu běží východním směrem přes Hradec nad Moravicí až k Ostravě, ačkoliv se lokálně klikatí v závislosti na morfologii terénu (Macoun 1982, 1987, 1989b). Oderskou část Moravské brány ledovec vyplnil širokým lalokem, sevřeným mezi Vítkovskou vrchovinou a Podbeskydskou pahorkatinou, do nichž pronikal terénními depresemi. Podél hranice zaledněné oblasti v Moravské bráně leží obce a města Dolní Lhota, Bílovec, Fulnek, Jeseník nad Odrou, Nový Jičín a Kopřivnice (Vitásek 1919; Czudek 1962; Menčík, Tyráček 1985; Macoun 1989b; Dvořák 1991; Tyráček 2011). V Podbeskydské pahorkatině v. od toku Ostravice je hranice zásahu ledovce asi nejzastřenější. Bludné balvany byly vymapovány 


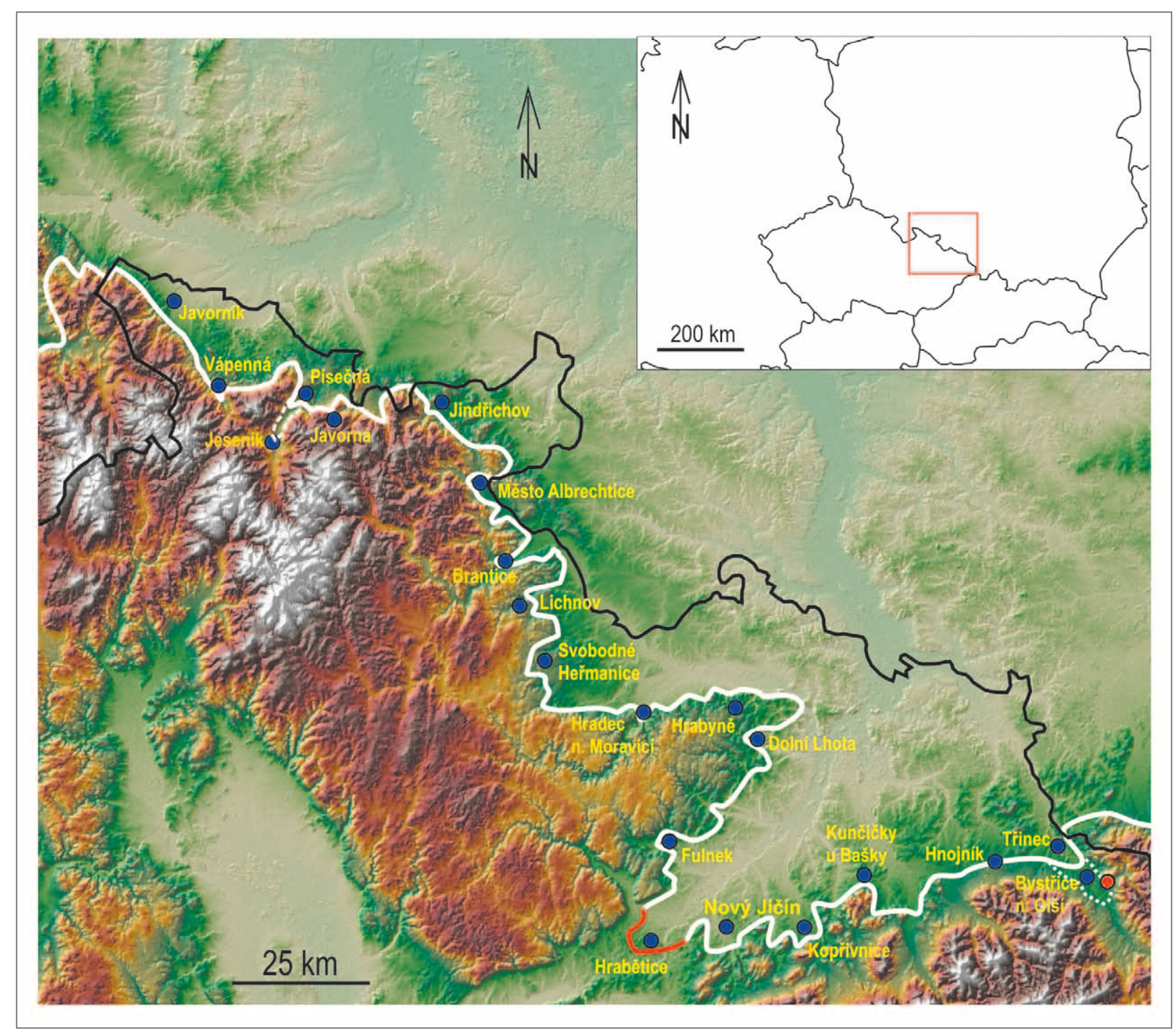

Obr. 1: Severoevropský ledovcový štít ve středním pleistocénu Východních Sudet a Vnějǐích Západních Karpat. Bílá linie: maximální rozsah elsterského ledovcového štítu. Červená linie: maximální rozsah sálského ledovcového štítu v Moravské bráně. Bíle čárkovaná linie: nejistý zásah ledovcového štítu v údolí Bělé. Bíle tečkovaně: zalednění údolí Olše s ohledem na nález pazourku. Červený bod: poloha nálezu pazourku. Černá linie: státní hranice ČR a Polska. Rozsah zalednění podle literatury citované v textu. Fig. 1: Continental glaciation of Eastern Sudetes and Outer Western Carpathians. White line: maximum extent Elsterian ice sheet; red line: maximum extent of Saalian ice sheet in Moravian Gate; white dashed line: uncertain extent of ice sheet in the Bělá River Valley; white dotted line: glaciated valley of the Olza River with respect to new find of an erratic flint; red dot: position of the flint find; black line: Czech/Polish state boundary. Ice-sheet extent based on the literature cited in the text.

mezi Frýdkem-Místkem a Frýdlantem nad Ostravicí, sv. od Frýdku-Místku a mezi Těrlickem a Třanovicemi (Vitásek 1938). Ledovcové sedimenty tvoří akumulace na rozvodní plošině Olešné a Ostravice mezi Palkovicemi a Baškou, sz. od Hnojníka a západně od Českého Těšína (Menčík, Tyráček 1985; Růžička 1992).

Kvartérně geologické výzkumy prokázaly v moravskoslezské glaciální oblasti dva ledovcové zásahy. Starší zásah spadá do elsterského glaciálu a mladší do prvního sálského glaciálu (Macoun et al. 1965; Nývlt et al. 2011). Během obou zalednění docházelo k dílčím ústupům a postupům ledovcového čela. Tyto oscilace se staly základem detailní stratigrafie jednotlivých regionálních zalednění (Macoun 1980; Růžička 2004), která však byla pro svou komplikovanost a obtížnou terénní aplikovatelnost kritizována (Czudek 2005). Podle Macouna et al. (1965) byl sálský ledovcový štít v celé moravskoslezské glaciální oblasti plošně rozsáhlejší. Novější práce (Nývlt et al. 2011) naopak předpokládají větší rozsah elsterského ledovce, s výjimkou jz. okraje oderské části Moravské brány, kde sálský ledovec dosáhl ve srovnání s elsterským ledovcem dále na JZ, a to až do prostoru mezi Bělotínským potokem a Hraběticemi (Nývlt et al. 2011; Tyráček 2011; Tyráček 2011). Ledovcový štít však nikdy přímo nepřekonal odersko-dunajské rozvodí východně od Hranic ani v Porubské bráně (Tyráček 2011).

Nejvyšší nadmořské výšky 545 m dosáhl ledovec na úbočí Rejvízské hornatiny (Gába 1972; Hanáček 2011). Rychlebské hory byly zaledněny do výše min. $480 \mathrm{~m} \mathrm{n}$. m. (Gába 1972). V Jindřichovické pahorkatině je výškový dosah ledovce uvažován v rozmezí 435-480 m (Zapletal 1966), v Nízkém Jeseníku ledovec dosáhl úrovně 340 m 
(Macoun 1980), v Podbeskydí 300-350 m (Menčík et al. 1983). Údaje se vztahují $\mathrm{k}$ nadmořské výšce sedimentů vzniklých v přímé nebo těsné souvislosti se samotným ledovcem (tilly, sedimenty tavných vod).

Ostravská pánev byla pokryta nejmocnější částí ledovcového štítu. Odhady mocnosti ledovce se ale značně liší v rozmezí od $200 \mathrm{~m}$ (Macoun et al. 1965) přes 70-100 m (Czudek 2005) na pouhých 50 m (Szponar 1986). Terminální část ledovcového laloku v Moravské bráně, tj. v oblasti Jeseníku nad Odrou, byla patrně mnohem tenčí (20-40 m, Czudek 2005). Na severním okraji Nízkého Jeseníku neměl ledovec přesahovat mocnost $50 \mathrm{~m}$ (Macoun 1980), na Novojičínsku v Podbeskydí dosahoval tlouštky 100 m (Menčík et al. 1983). V přechodu z Osoblažské nížiny do Jindřichovické pahorkatiny se mocnost ledovce snižovala z $230 \mathrm{~m}$ na desítky metrů (Zapletal 1966) a v podstatě stejný vývoj je doložen i na přechodu z Vidnavské nížiny přes Žulovskou pahorkatinu na svahy Rychlebských hor (Hanáček et al. 2021).

Přehled dosavadních poznatků jasně ukazuje na široký rozsah odhadů mocnosti ledovcového štítu, která vyplývá z nejasné hranice jeho maximálního rozsahu. Ta se zdá být známá pouze z celkového pohledu, ovšem v detailu je situace odlišná. Hranici zásahu ledovce na svazích a v údolích, ukloněných proti ledovcovému štítu, je velmi obtížné rekonstruovat kvůli poledovcovým geologickým procesům (Prosová 1981). Počátek ústupu ledovce byl spojen s iniciací koluviálních, aluviálních a fluviálních procesů, které ještě zesílily po definitivním odlednění a degradaci permafrostu. Z osních částí údolí byly ledovcové sedimenty fluviálně erodovány. Relikty ledovcových klastik po stranách údolí byly erodovány nebo pohřbeny koluviálními a aluviálními procesy. Terénní mapování maximálního zásahu ledovce je těmito okolnostmi velmi zkomplikováno. Rozsah ledovce je pak dedukován podle prokázaného výškového zásahu ledovce v bezprostředním severním sousedství problematických terminálních zón. Př́́kladem je třeba podrobně studovaná otázka rozsahu ledovcového laloku v údolí řeky Bělé mezi Rejvízskou hornatinou a Rychlebskými horami s možností zásahu ledovce až do Jesenické kotliny (Gába 1972; Růžička 2004; Nývlt et al. 2011; Hanáček et al. 2018), viz též diskusi $\mathrm{v}$ tomto článku.

Předložený příspěvek se zabývá eratikem baltského pazourku z údolí Olše u Bystřice. Ačkoliv se jedná o jediný klast, je tento nález zajímavý s ohledem na širší kvartérně geologické souvislosti. Úsek údolí Olše jv. od Českého Těšína dosud neposkytl žádné informace o zásahu ledovcového štítu. Přesto je průnik okrajové zóny ledovcového štítu do této oblasti předpokládán všemi autory (Drahný 1923; Macoun et al. 1965; Růžička 2004; Nývlt et al. 2011). Otázka postupu ledovce proti toku preglaciální Olše dále na JV od Českého Těšína je tedy jedním z nedořešených problémů vymezení maximální hranice středněpleistocenního ledovcového štítu. Proto má jakýkoliv, byt individuální doklad přítomnosti nebo blízkosti ledovce v tak nepoznané oblasti svůj význam.

\section{Lokalita a popis nálezu}

Koncem 70. let byl nalezen v Bystřici nad Olší, v místní části Pod Prašivou, pazourkový klast na zahradní parcele domu č. p. 751 (obr. 2). Souřadnice místa nálezu

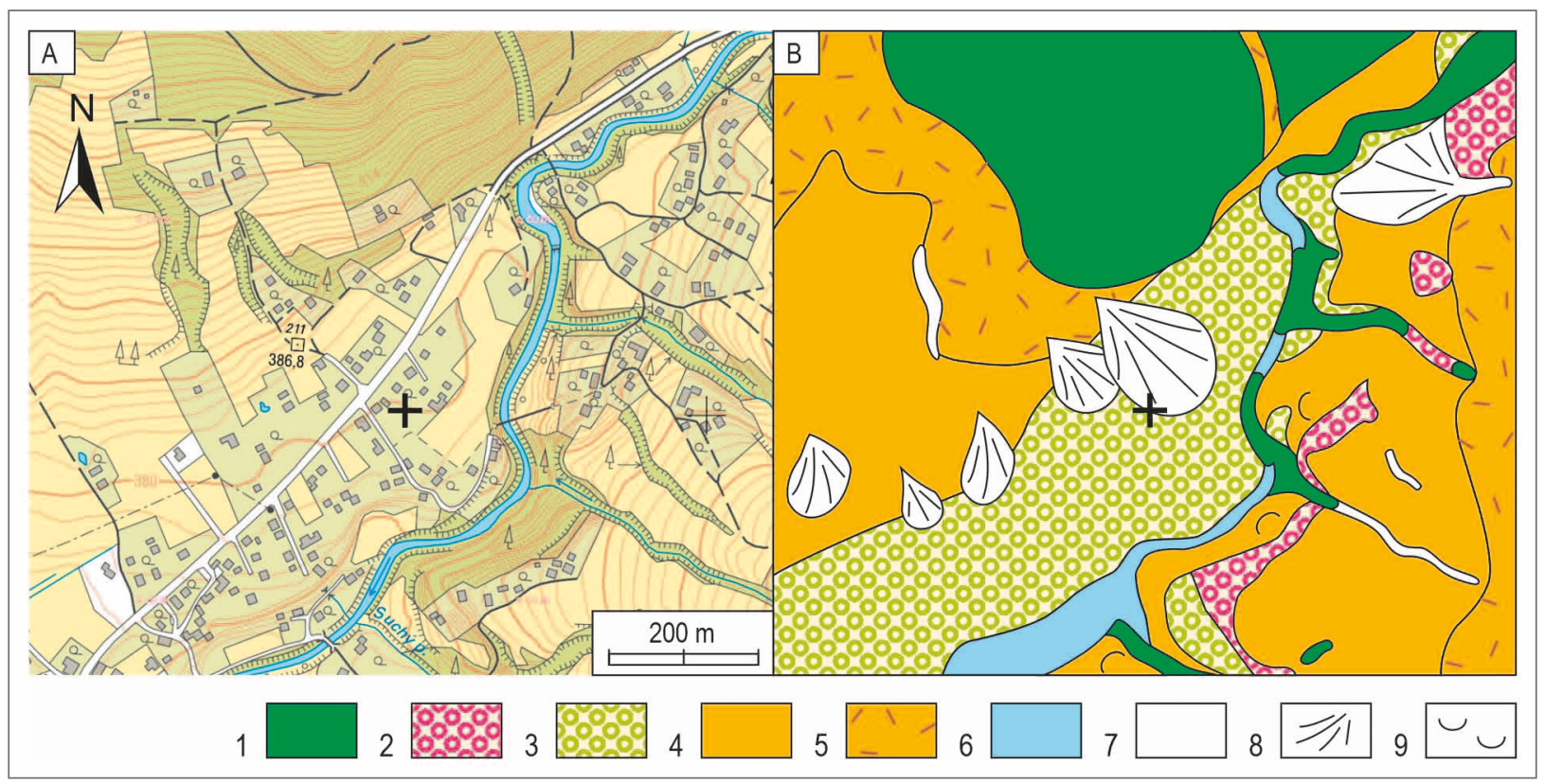

Obr. 2: Situace nálezu pazourku v Bystřici nad Olší. A - místo nálezu v topografické mapě označené křižkem; B - místo nálezu v geologické mapě. 1 - předkvartérní jednotky karpatského flyše; 2 - fluviální štěrkovité písky (sálský glaciál); 3 - fluviální štěrkovité písky (viselský glaciál); 4 - deluviální písčitohlinité sedimenty; 5 - deluviální kamenitohlinité sedimenty; 6 - fluviální písčité štěrky (holocén); 7 - koluviálně-fluviální sedimenty; 8 - výplavové kužely; 9 - sesuvy. Podle Menčíka (1988b); upraveno. Fig. 2: Position of the flint find in Bystřice nad Olší. A - position in the topographic map indicated by a cross; B - position in the geological map. 1 - Pre-Quaternary units of the Carpathian Flysch; 2 - fluvial gravelly sand (Saalian); 3 - fluvial gravelly sand (Weichselian); 4 - colluvial sandy-loam; 5 - colluvial coarse-grained sediments; 6 - fluvial sandy gravel (Holocene); 7 - colluviofluvial sediments; 8 - alluvial fan; 9 - landslide. Modified after Menčík (1988b). 
odečtené z ortofoto na GoogleMaps jsou: 49³8‘55.6“ N; $18^{\circ} 44^{\prime} 26.8^{\prime \prime E}$. Nadmořská výška nálezu činí $380 \mathrm{~m}$. Klast byl objeven v mělkém výkopu, v hloubce kolem $30 \mathrm{~cm}$, v zahliněném fluviálním štěrku, který je interpretován jako viselská údolní fluviální akumulace potoka Hluchová (Menčík, Tyráček 1985; Menčík 1988a; b). Údolní terasa tvořená touto akumulací pokrývá většinu plochého dna Hluchové mezi Bystřicí nad Olší a Nýdkem až k místu, kde je Hluchová sevřena mezi masívy Prašivé a Polední hory. Fluviální štěrk tvořící těleso údolní terasy byl ve výkopu překryt tenkým humózním hlinitým sedimentem, který podle geologického kontextu představuje distální část drobného aluviálního kužele. Svědčí pro to morfologie terénu okolo lokality i vymapované malé aluviální kužely podél sz. okraje údolí Hluchové (Menčík, Tyráček 1985; Menčík 1988, viz obr. 2).

Klast představuje téměř kompletní pazourkovou konkreci se zbytkem původního povrchu s výjimkou několika čerstvějších lasturnatých lomů na jedné straně. Tvar konkrece je zhruba kuželovitý, o rozměrech přibližně $7 \times 6 \times 4 \mathrm{~cm}$ (obr. $3 \mathrm{a}-\mathrm{c}) . \mathrm{Z}$ petrografického hlediska jde o žlutošedě zbarvený, zčásti průsvitný silicit. Obsahuje jehlice hub, osten ježovky a úlomek mechovky (obr. 3d, e). Mechovka je blíže neurčitelný cyclostomátní typ (rod ?Mecynoecia nebo ?Tervia), který by mohl svědčit spíše pro spodnopaleocenní stáří pazourku (dan) a původ v mechovkovém nebo saltholmském vápenci na dánských ostrovech nebo v nejjižnějším Švédsku (K. Zágoršek, emailová komunikace, viz rovněž Gába, Pek 1999). Povrch klastu včetně odštípnutých ploch je jemně abradovaný a lesklý. Nejstarší plochá strana klastu nese zřetelné, vzájemně se prolínající úderové stopy (obr. 3f). V hmotě pazourku prosvítá vlasová puklina probíhající dvěma hlavními odštíplými plochami.

\section{Interpretace}

Studovaný pazourek nenese stopy antropogenního opracování. Odštíplé plochy jsou ploché a postrádají charakteristickou morfologii úštěpů po úderu otloukačem, která je typická pro pazourková jádra (P. Škrdla, I. Mateiciucová, ústní sdělení). Neexistují tedy důkazy svědčící o př́padné souvislosti nálezu pazourku s aktivitou člověka.

Úderové plochy na ploché straně klastu vznikly účinkem př́iboje na pobřeží Baltského moře. Jelikož je to zjevně nejstarší povrch klastu, představuje mořská abraze první z procesů formujících tvarové vlastnosti klastu. Z ledovcových uloženin jsou popsány i dokonale oválné klasty pazourků poseté úderovými stopami a interpretované jako plážové valouny - tzv. wallsteiny (Gába, Pek 1999). Následoval vznik velkých štěpných ploch, které se mohly utvořit rozpuknutím klastu důsledkem tlaku při ledovcovém transportu nebo interakcemi klastů v glacifluviálním či dokonce až finálním fluviálním transportu. Defekty na hranách velkých ploch mohou být stopami po trakčním transportu v glacifluviálním nebo finálním fluviálním prostředí. Exponovaná strana klastu byla nevýrazně eolizovanána za vzniku drobných lesklých plošek, které jsou v někdejší periglaciální zóně severoevropského ledovcového štítu častým projevem větrné koraze (Gába, Pek 1999). Periglaciální klima mohlo rovněž způsobit vznik mrazových puklinek v klastu.

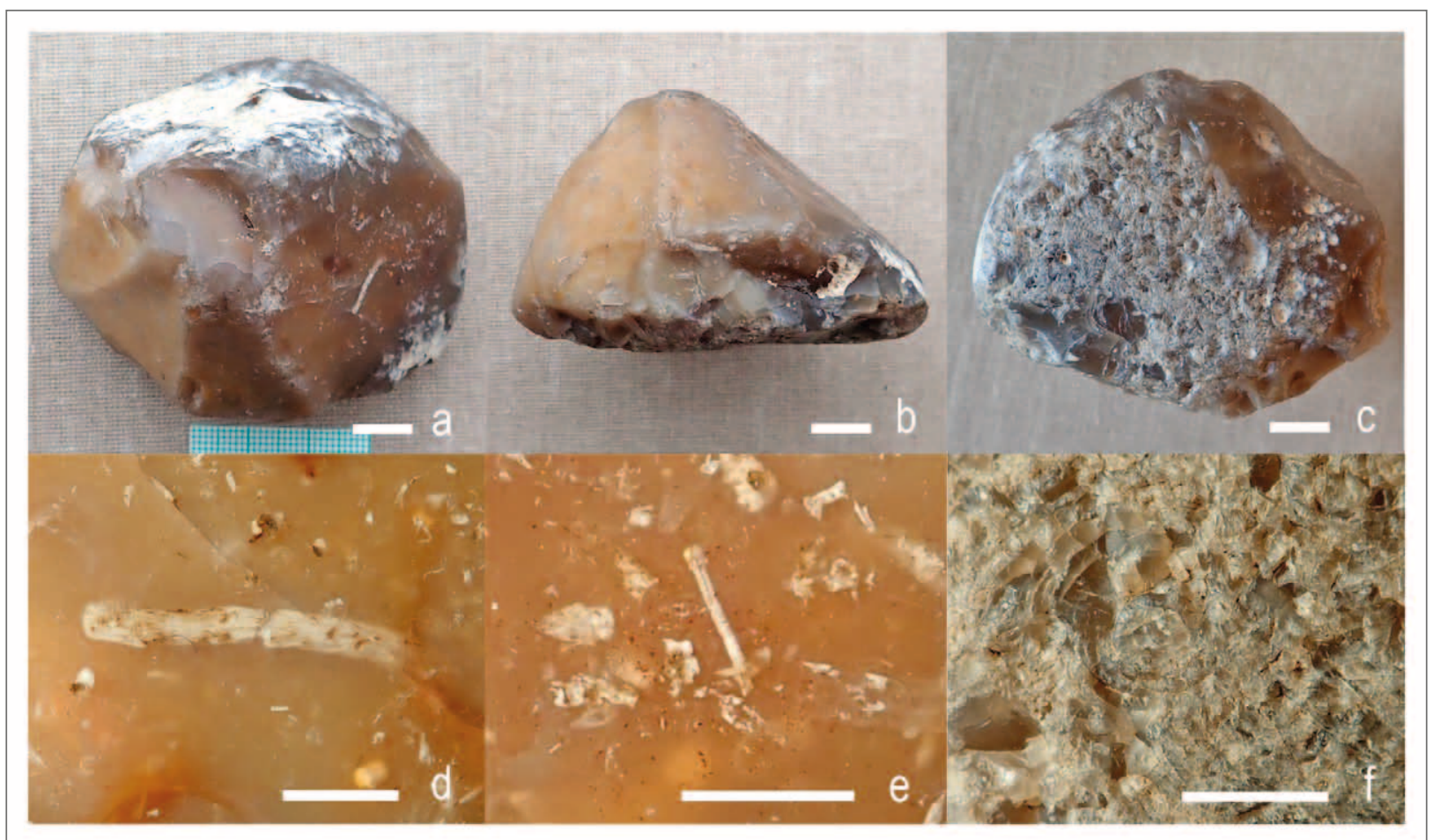

Obr. 3: a, b, c - baltský pazourek z Bystřice nad Olší; d - zoarium cyklostomátní mechovky; e - osten ježovky; f - úderové stopy na povrchu pazourku. Měŕítko: a-c $-10 \mathrm{~mm}$;, $\mathrm{f}-5 \mathrm{~mm}$; e $-2 \mathrm{~mm}$.

Fig. 3: a, b, c - Baltic flint from Bystřice nad Olší; d - zoarium of cyclostomate bryozoan; e - echinoid spine; $\mathrm{f}$ - percussion marks on the surface of the flint. Scale bar: $a-c-10 m m ; d, f-5 m m ; e-2 m m$. 


\section{Diskuze}

V oblasti středněpleistocenního severoevropského ledovcového štítu představuje nálezová oblast pazourku jeden $\mathrm{z}$ nejvíce problematických úseků, především $\mathrm{z}$ důvodu nedostatku terénních poznatků. Ledovcové sedimenty nejsou z blízkého okolí naleziště známy. Nejbližší ledovcové sedimenty od údolí Hluchové byly vymapovány i odkryty západně od Českého Těšína (Gába 1976; Růžička 1992), zhruba $15 \mathrm{~km}$ sz. směrem od studované lokality. Rozsah zalednění v údolí Olše byl různými autory zakreslen značně rozdílně (obr. 1). Podle většiny názorů tvořil ledovec jjv. od Českého Těšína jen úzký, krátký výběžek, sahající do oblasti Třince (Drahný 1923; Růžička 2004; Nývlt et al. 2011). Podle menšinového názoru tvořil ledovec $\mathrm{v}$ údolí Olše mohutný lalok dosahující až k Jablunkovu (Macoun et al. 1965). Popisovaný pazourek tedy ležel bud’ v terminální pozici krátkého ledovcového laloku, prrípadně v jeho blízkém předpolí, nebo podél boční strany velkého ledovcového laloku. Poloha nálezu v údolí bočního přítoku Olše podporuje spíše představu o robustnějším ledovcovém laloku. Pazourek by pak pocházel z boční morény tohoto laloku. Tuto paleoglaciologickou pozici podporuje i vysoká nadmořská výška nálezu (380 m), která je vyšší než běžně uváděné výskyty ledovcových uloženin v blízkém okolí (Menčík, Tyráček 1985; Růžička 1992).

Paleogeografická situace studovaného úseku Olše připomíná $\mathrm{v}$ úvodu zmíněný a neméně problematický

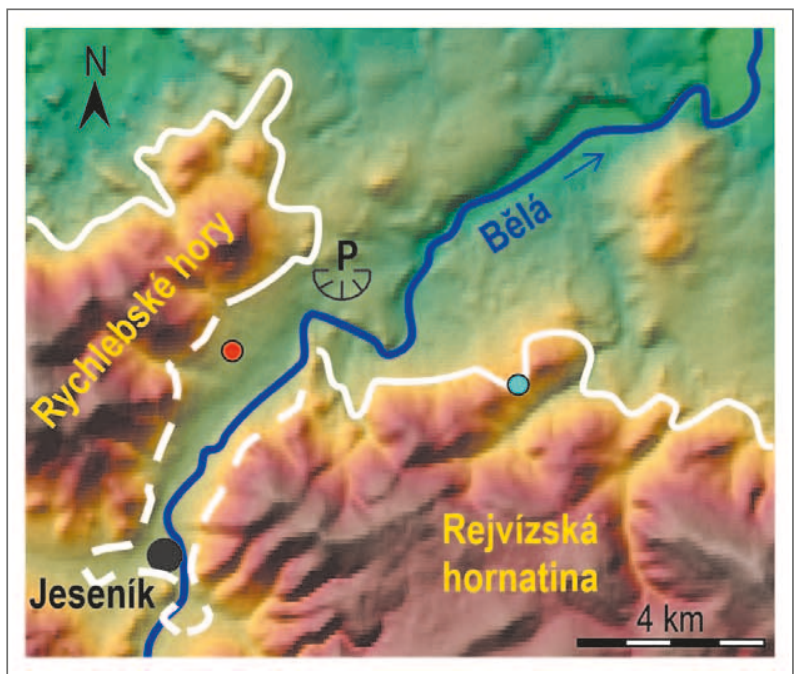

Obr. 4: Rekonstrukce rozsahu středněpleistocenního ledovcového štítu v údolí řeky Bělé mezi Rychlebskými horami a Rejvízskou hornatinou. Plná bílá linie: prokázaný rozsah ledovce; přerušovaná bílá linie: možný zásah ledovce k Jeseníku. Modrý bod: eratika v nadmořské výšce $545 \mathrm{~m}$ na sz. svahu Rejvízské hornatiny; červený bod: eratika v údolí Bělé. P - terminoglaciální delta ledovcem hrazeného jezera vzniklého během ústupu ledovce (pískovna v Písečné).

Fig. 4: Reconstruction of the Middle Pleistocene ice sheet extent in the Bělá River Valley between Rychleby Mts. and Rejvíz Upland. White full line: Certain ice sheet extent. White dashed line: Questionable ice sheet extent. Blue dot: Erratics on the NW slope of Rejvíz Upland ( 545 m a. s. 1.). Red dot: Erratics in the Bělá River Valley. P - Terminoglacial delta of ice-dammed lake originating during the ice sheet retreat (Písečná sandpit). jižní úsek údolí řeky Bělé mezi Rejvízskou hornatinou a Rychlebskými horami (obr. 4). Na severozápadním svahu Rejvízské hornatiny byly tilly s eratiky objeveny v horském sedle v nadmořské výšce 545 m (Gába 1972; Cháb et al. 2004). Tento nejvyšší výskyt uloženin pevninského ledovce v ČR dokazuje přímý zásah ledovce do horského sedla. Glacifluviální toky pak před čelo ledovce v sedle uložily terminoglaciální výplavový kužel (Hanáček 2011). Na základě prokázaného zásahu ledovcového štítu do uvedené výškové úrovně předpokládají někteří autoři (nověji Cháb et al. 2004; Růžička 2004; Nývlt et al. 2011) zásah ledovcového štítu až do Jesenické kotliny, do oblasti dnešního města Jeseník. Přímo v údolí Bělé však byla eratika nalezena $\sim 4-5 \mathrm{~km}$ s. od Jeseníku (Gába 1972; Prosová 1981). Údolí Bělé sv. od Jeseníku bylo navíc během deglaciace zatopeno jezerem, hrazeným ledovcovým štítem i pohořím. Toto jezero bylo intenzivně zanášeno hrubozrnným materiálem přinášeným terminoglaciální deltou, jejíž sedimenty se zachovaly $6,5 \mathrm{~km}$ sv. od Jeseníku (Hanáček et al. 2018). Eratika přímo v údolí Bělé byla do termino- až proglaciální zóny vyplavována a nemusela být proto na svá nynější naleziště nutně dopravena př́mo ledovcem (Prosová 1981). Nález pazourku vysoko v boční straně říčního údolí Olše u Bystřice podporuje paleogeografické názory o průniku laloků ledovcového štítu hlouběji do Sudet a Karpat. Tato úvaha se vztahuje rovněž na údolí Bělé i přes nejasný způsob transportu eratik v bělském údolí do jejich nynější pozice.

Zóna kontaktu okraje severoevropského ledovcového štítu s úbočími Sudet a Karpat představuje specifickou okrajovou zónu pevninského ledovce, která ve střední Evropě vznikla pouze během nejdelších glaciálů, elsterského a prvního sálského, kdy se ledovcový štít rozrostl až na samotná úbočí zmíněných pohoří (Macoun et al. 1965; Růžička 2004; Nývlt et al. 2011). Mezi ledovcovým štítem a pohořím vznikla krátkodobá depoziční pánev, která se svým tvarem, průběhem a členitostí přizpůsobovala průběhu horských svahů, říčních údolí a ledovcového čela. Pánev se nevyvíjela synchronně jako spojený prostor, protože její jednotlivé úseky vznikaly a zanikaly v závislosti na celkovém šíření i místní dynamice ledovcového okraje. Společným znakem všech úseků pánve byla mimořádná dynamika depozičních a erozních procesů (detailně v moravskoslezské glaciální oblasti např. Prosová 1981; Menčík et al. 1983; Cháb et al. 2004). V této podhorsko-ledovcové pánvi probíhaly koluviální a aluviálně-fluviální procesy související s pohořím (podhorské procesy a sedimenty). Zároveň zde působily glacifluviální, glacilakustrinní a glacigenní procesy s. s., tj. glacitektonika a tvorba morén, související s přítomností ledovcového štítu (ledovcové procesy a sedimenty). Pánev prodělala tři hlavní fáze vývoje: 1 . předledovcová fáze (iniciální eroze v údolích a následná akumulace podhorských sedimentů); 2. ledovcová fáze (přiblížení, zásah a ústup ledovce, zaznamenané glacifluviálními/glacilakustrinními sedimenty postupové fáze, ledovcovou erozí a glacigenní sedimentací s. s. a nakonec glacifluviálními/glacilakustrinními sedimenty ústupové fáze); 3. poledovcová fáze (eroze, obnova předledovcové ř́iční sítě s lokálními odchylkami a podhorská 
sedimentace). Právě za maximálního rozsahu ledovcového štítu zde krátkodobě převládly ledovcové procesy nad podhorskými procesy (např. Salamon 2014). V této etapě uvnitř pánve dominovala agradace sedimentů nad erozí v souladu s modelem Brodzikowského a van Loona (1991). Pánev se intenzivně vyplňovala hlavně ledovcovými sedimenty (Menčík et al. 1983). S ústupem ledovce nastal obrat. Došlo k energické obnově podhorských procesů, intenzivní hloubkové i plošné erozi především ledovcových sedimentů a redepozici jejich materiálu do nových podhorských uloženin (Macoun et al. 1965; Cháb et al. 2004). Na př́ikladu podhưř́ Rychlebských hor a Rejvízské hornatiny označuje Prosová (1981) zónu interakcí podhorských a ledovcových procesů jako oscilační zónu kontinentálního ledovce.

Právě ve fázi maximálního rozšíření ledovcového štítu došlo $\mathrm{k}$ průniku ledovce do údolí řek, otevřených celkově severním směrem. $\mathrm{V}$ těchto paleogeografických situacích však narážíme na problémy, které byly konkrétně prezentovány na př́ikladu údolí Bělé. Rozsah ledovce je vymezován podle plošného a výškového výskytu eratik a ledovcových sedimentů, př́íp. tvarů reliéfu v terénu. Eratický materiál je ale součástí i terminoglaciálních až proglaciálních výplavových sedimentů. V říčních údolích vznikala terminoglaciální jezera, protože po zahrazení ledovcem se fluviální údolí měnila $v$ glacilakustrinní vnitrohorské pánve, intenzivně vyplňované hrubými deltovými klastickými sedimenty (Salamon 2014; Hanáček et al. 2018; Krzyszkowski 2013; Krzyszkowski et al. 2019). V severních Čechách, Rejvízké hornatině a Porubské bráně progradovaly před nejexponovanějšími výběžky ledovce terminoglaciální kužely a údolní proglaciální řeky, transportující eratika do předpolí zaledněného území (Nývlt, Hoare 2000; Tyráček 2011; Hanáček 2011). Jelikož se v úvodu citované údaje o nadmořské výšce zalednění vztahují k různým typům ledovcových sedimentů, lze předpokládat, že povrch samotného ledovce mohl sahat ještě výše, určitě o minimálně odhadované mocnosti v různých úsecích periferie ledovcového štítu.

Severoevropský pevninský ledovec byl během svého maximálního rozsahu polytermální s chladnou bází pod svými okraji (Salamon 2016; Hanáček et al. 2021). Ledovce s chladnou bází deformují podložní permafrost (Waller et al. 2012). Z tohoto důvodu se při bázi a podél čela severoevropského ledovcového štítu patrně vyskytovaly bloky substrátu odtrženého z podložního permafrostu. V říčních údolích byl permafrost tvořen aluviálně-fluviálními klastickými sedimenty z předledovcové fáze vývoje. Během deglaciace se do tillů, glacifluviálních a glacideltových sedimentů dostávalo velké množství provenienčně místních klastů, pocházejících právě z erodovaného permafrostu. Proto jsou sedimenty okrajových zón ledovcového štítu v podhorské oblasti složeny převážně z místních hornin, zatímco eratika tvoří příměs většinou jen v prvních \% (Gába 1981; Nývlt, Hoare 2000; Hanáček 2011, 2014). Ještě u Českého Těšína obsahují glacifluviální sedimenty ve štěrkové frakci jen necelé $1 \%$ eratik, zbytek připadá na místní flyšové horniny a křemen (Gába 1976).
Pokud byl pazourek skutečně součástí boční morény, pak se nacházel právě v akumulačním tvaru ledovcového reliéfu, který je u všech ledovcových splazů tvořen hlavně klasty z přiléhajících svahů (např. Hambrey 1994). Tím lze vysvětlit naprostou ojedinělost nálezu. Dále od pohoří podíl eratik výrazně roste (např. na Hlučínsku, viz Růžička 1995; Sedláček 2008). Během deglaciace je nutné uvažovat o vyplňování terminoglaciálních jezer nejen materiálem z ledovce, nýbrž i sedimenty přinášenými z pohoří důsledkem obnovy říční sítě.

Chladný bazální režim v podhorské okrajové zóně ledovcového štítu limituje možnost mapování rozsahu ledovce podle glacigenních erozních tvarů reliéfu. Ledovce s chladnou bází totiž své podloží téměř nemodifikují (např. Hall, Glasser 2003). Proto nelze absenci stop erozního geomorfologického působení ledovce v údolí Bělé (viz Prosová 1981), ani v podobných údolích považovat za důkaz nepřítomnosti ledovce. Aktivní ledovcová eroze vedoucí ke vzniku oblíků se projevila jen lokálně v podhůří Jizerských hor a v Jindřichovické pahorkatině (Perečková 2008; Janásková 2009). Další oblíkům podobné elevace (Prosová 1981) jsou tvary bazální zvětrávací plochy, nevytvořené ledovcem (Vídeňský et al. 2007).

\section{Závěr}

Údolí horských řek orientovaná proti postupujícímu ledovcovému štítu jsou pro rekonstrukce výškového i plošného rozsahu zalednění nejproblematičtějšími úseky. Rychlé erozně-depoziční změny způsobily, že eratika byla resedimentována mimo samotný ledovec nebo, po odlednění, zpět od nejzazší linie rozsahu ledovcového štítu a na něj vázaných lokálních depocenter. Relativní podíl eratik v sedimentech byl zároveň značně snížen převahou místního materiálu v terminoglaciálních prostředích i následným poledovcovým př́nosem nového materiálu z nitra pohoří. Ojedinělý nález eratika v poledovcových fluviálních sedimentech v údolí Hluchové ukazuje na mohutnější zásah ledovce do údolí Olše. V širším kontextu tento nález podporuje maximalističtější názory na průnik laloků ledovcového štítu do údolí horských řek v moravskoslezské glaciální oblasti. Podrobné řešení této otázky bude ale nutně vyžadovat mapování dalších případných výskytů eratik v podhorském terénu.

\section{Poděkování}

Autoři děkují Dr. Petru Škrdlovi a Dr. Inně Mateiciucové za cennou diskusi $k$ otázce opracování nalezeného kusu pazourku. Dík patři rovněž Kamilu Zágoršekovi za odborné zhodnocení fosilní mechovky zachovalé v pazourku. Recenzentům Danielu Nývltovi a Antonínu Přichystalovi jsme zavázáni za kritické posouzení rukopisu. Předložený článek byl vypracován v rámci interního projektu ČGS č. 310970 a v rámci výzkumné činnosti Vlastivědného muzea Jesenicka (VMJ_GEO_KV). Výzkum byl rovněž podpořen projektem ECOPOLARIS, číslo CZ.02.1.01/0.0/ 0.0/16_013/0001708 financovaném Ministerstvem školství, mládeže a tělovýchovy České republiky. 


\section{Literatura}

Brodzikowski, K., Van Loon, A. J. (1991). Glacigenic Sediments. - Elsevier. 674 s.

Czudek, T. (1962). Nové poznatky o rozsahu halštrovského zalednění v Moravské bráně. - Přírodovědecký časopis slezský, 23, 362-364.

Czudek, T. (1980). Ledovcové sedimenty u obce Svobodné Heřmanice v Nízkém Jeseníku. - Časopis Slezského muzea Opava (A), 29, 53-56.

Czudek, T. (2005). Vývoj reliéfu krajiny České republiky v kvartéru. - Moravské zemské muzeum. 238 s.

Drahný, F. (1923). Přehled geologických poměrů Slezska. 29 s.

Dvořák, J. (1991). Geologická mapa ČR. List 15-34 Vítkov. - Ústřední ústav geologický.

Gába, Z. (1972). Nejzazší výskyty uloženin kontinentálního zalednění na Jesenicku. - Časopis Slezského muzea (A), 21, 135-139.

Gába, Z. (1976). Valounové analýzy vodně ledovcových uloženin moravskoslezské oblasti. - Časopis Slezského muzea (A), 25, 57-62.

Gába, Z. (1981). Uloženiny kontinentálního ledovce u Písečné na severní Moravě. - Časopis Slezského Muzea Opava (A), 30, 3 , 241-253.

Gába, Z., Pek, I. (1999). Ledovcové souvky moravskoslezské oblasti kvartérního kontinentálního zalednění. 2. Sedimentární souvky. - Acta Universitatis Palackianae Olomucensis, Facultas Rerum Naturalium, Geologica, 36, 13-37.

Hall, A. M., Glasser, N. F. (2003). Reconstructing the basal thermal regime of an ice stream in a landscape of selective linear erosion: Glen Avon, Cairngorm Mountains, Scotland. - Boreas, 32, 191-207.

Hambrey, M. J. (1994). Glacial Environments. - UCL Press. London. 296 s.

Hanáček, M. (2011). Sedimenty terminoglaciálního kuželu v údolí Javorné na Zlatohorsku. - Acta Musei Moraviae, Scientiae geologicae, 96, 61-86.

Hanáček, M. (2014). Význam valounových analýz ledovcových sedimentů pro paleogeografické rekonstrukce pleistocenního kontinentálního zalednění Jesenicka. - Geologické výzkumy na Moravě a ve Slezsku, 21, 17-24. https://doi.org/10.5817/ GVMS2014-1-2-17

Hanáček, M., Nývlt, D. (2009). Subglaciální štěrkovité tilly u Jindřichova na Osoblažsku. - Časopis Slezského zemského muzea (A), 58, 193-214.

Hanáček, M., Nývlt, D., Jennigs, S. J. A. (2021). Thermal basal regime of the Elsterian ice-sheet marginal zone in a hilly mountain foreland, Rychleby Mts., Eastern Sudetes. - Boreas, 50, 582-605. https://doi.org/10.1111/bor.12505

Hanáček, M., Nývlt, D., Skácelová, Z., Nehyba, S., Procházková, B., Engel, Z. (2018). Sedimentary evidence for an ice-sheet dammed lake in a mountain valley of the Eastern Sudetes, Czechia. - Acta Geologica Polonica, 68, 107-134. https://doi. org/10.1515/agp-2017-0032

Cháb, J., Čurda, J., Kočandrle, J., Manová, M., Nývlt, D., Pecina, V., Skácelová, D., Večeřa, J., Žáček, V. (2004). Základní geologická mapa České republiky 1:25 000 list 14-224 Jeseník s Vysvětlivkami. - Česká geologická služba.

Janásková, B. (2009). The origin of rounded granite elevations in the northern foothills of the Jizera Mountains. - Geomorphologia Slovaca et Bohemica, 9, 7-16.

Kroutilík, V. (1960). Zpráva o výzkumu glacigenních sedimentů mezi Opavou a Krnovem. - Př́rodovědecký časopis slezský, 21 , 243-253.

Krzyszkowski, D. (2013). Stratygrafia plejstocenu w południowo-zachodniej Polsce. - In: B. Przybylski, D. Krzyszkowski (eds): XX. Konferencja Stratygrafia plejstocenu Polski. Plejstocen przedpola Sudetów Środkowych, 16-26, Lasocin.

Krzyszkowski, D., Krzywicka, A., Wachecka-Kotkowska, L., Sroka, W. (2019). The Middle Pleistocene glaciolacustrine environment of an ice-dammed mountain valley, Sudeten Mountains, Poland. - Boreas, 48, 966-987. https://doi.org/10.1111/bor.12396

Macoun, J. (1980). Paleogeografický a stratigrafický vývoj Opavské pahorkatiny v pleistocénu 1. - Časopis Slezského muzea v Opavě (A), 29, 113-132.

Macoun, J. (1982). Geologická mapa ČSR. List 15-23 15-41 Hlučín. - Ústřední ústav geologický. Praha.

Macoun, J. (1987). Geologická mapa ČSR. List 15-32 Opava. - Ústřední ústav geologický. Praha.

Macoun, J. (1989a). Geologická mapa ČSR. List 15-14 Krnov. - Ústřední ústav geologický. Praha.

Macoun, J. (1989b). Geologická mapa ČSR. List 15-43 Ostrava. - Ústřední ústav geologický. Praha.

Macoun, J., Šibrava, V., Tyráček, J., Kneblová-Vodičková, V. (1965). Kvartér Ostravska a Moravské brány. - Ústřední ústav geologický. 419 s. Praha.

Menčík, E., Adamová, M., Dvořák, J., Dudek, A., Jetel, J., Jurková, A., Hanzlíková, E., Houša, V., Peslová, H., Rybářová, L., Šmíd, B., Šebesta, J., Tyráček, J., Vašíček, Z. (1983). Geologie Moravskoslezských Beskyd a Podbeskydské pahorkatiny. - Ústřední ústav geologický, Praha. 304 s.

Menčík, E. (1988a). Geologická mapa ČSR, list 26-11, 16-33 Jablunkov, měřítko 1 : 50 000. - Ústřední ústav geologický. Praha.

Menčík, E. (1988b). Základní geologická mapa ČSSR, Měřítko 1 : 25 000, list 26-111 Bystřice. - Ústřední ústav geologický, Praha.

Menčík, E., Tyráček, J. (1985). Přehledná geologická mapa Beskyd a Podbeskydské pahorkatiny v měřítku $1: 100$ 000. - Ústřední ústav geologický. Praha.

Nývlt D., Engel Z., Tyráček J. (2011). Pleistocene glaciations of Czechia. - In: Ehlers J., Gibbard P. L., Hughes P. D. (eds): Quaternary Glaciations - Extent and Chronology Part IV - a closer look. Developments in Quaternary Science, 37-46, Elsevier. https://doi.org/10.1016/B978-0-444-53447-7.00004-0

Nývlt, D., Hoare, P. G. (2000). Valounové analýzy glacifluviálních sedimentů severních Čech. - Věstník Českého geologického ústavu, 75, 121-126.

Otava, J. (1992a). Geologická mapa ČR. List 15-13 Vrbno pod Pradědem. - Český geologický ústav. Praha

Otava, J. (1992b). Geologická mapa ČR. List 15-11 Zlaté Hory. - Český geologický ústav. Praha

Perečková, N. (2008). Roches moutonnées in the Osoblaha region. - GeoScape, 1, 9-14.

Prosová, M. (1981). Oscilační zóna kontinentálního ledovce. Jesenická oblast. - Acta Universitatis Carolinae, Geologica, 3, $265-294$. 
Růžička, M. (1992). Geologická mapa ČR. List 15-44 Karviná. - Český geologický ústav. Praha.

Růžička, M. (1995). Genesis and petrography of glacial deposits in the Czech Republic. - In: Ehlers, J., Kozarski, S., Gibbard, P. (eds): Glacial deposits in North-East Europe, 407-420, A. A. Balkema, Rotterdam/Brookfield.

Růžička, M. (2004). The Pleistocene glaciation of Czechia. - In: Ehlers, J., Gibbard, P. L. (eds): Quaternary Glaciations. - Extend and Chronology, 27-34, Elsevier.

Salamon, T. (2014). Rozwój strefy glacimarginalnej na przedpolu Beskidu Śląskiego (dział bielski Pogórza Śląskiego). - Przekląd Geologiczny, 62, 103-110.

Salamon, T. (2016). Subglacial conditions and Scandinavian Ice Sheet dynamics at the coarse-grained substratum of the fore-mountain area of southern Poland. - Quaternary Science Reviews, 151, 72-87. https://doi.org/10.1016/j.quascirev.2016.09.002

Sedláček, J. (2008). Studium sedimentů kontinentálního zaledněni ve vychodní časti Opavska. - MS, diplomová práce. Př́rodovědecká fakulta Masarykovy univerzity. Brno.

Szponar, A. (1986). Chronostratigraphy and the stages of deglaciations in the Sudetes foreland area in the period of the Middle-Polish glaciation. - Acta Universitatis Wratislaviensis. Studia Geograficzne, 45, 1-202.

Tyráček, J. (2011). Continental glaciation of the Moravian Gate (Czech Republic). - Antropozoic, 27, 39-49.

Vídeňský, A., Nývlt, D., Štěpančíková, P. (2007). Příspěvek k otázce vzniku granitoidních elevací v západní části Černovodské pahorkatiny, žulovský batolit. - Geologické výzkumy na Moravě a ve Slezsku, 14, 35-39.

Vitásek, F. (1919). Příspěvky ku poznání diluvia horního poříčí Odry. - Sborník České společnosti zeměvědné, 25, 1-21.

Vitásek, F. (1938). Morfologický vývoj těšínského Podbeskydí. - Spisy vydávané Přírodovědeckou fakultou Masarykovy university, 250, 3-18.

Waller, R. I., Murton, J. B., Kristensen, L. (2012). Glacier-permafrost interactions: Processes, products and glaciological implications. - Sedimentary Geology, 255-256, 1-28. https://doi.org/10.1016/j.sedgeo.2012.02.005

Zapletal, L. (1966). Geomorfologie Osoblažské pahorkatiny. - Acta Universitae Palackianae Olomucensis, Facultas Rerur Naturalium, Geographica-Geologica, 7, 13-188. Praha. 